\title{
Mass transfer and physicochemical characteristics of turkey neck meat during dry salting
}

Transferência de massa e características físico-químicas da carne de pescoço de peru durante a salga seca

\author{
J. C. M. Mota ${ }^{1}$; L. L. F. Cavalcanti ${ }^{1}$; L. S. Soares ${ }^{2}$; M. de Lima ${ }^{*}$ \\ ${ }^{I}$ Department of Chemical Engineering, Food Engineering Course, Federal University of Uberlândia - UFU, Campus \\ Patos de Minas, 38700-128, Patos de Minas-MG, Brazil \\ ${ }^{2}$ Department of Chemical Engineering and Food Engineering, Technology Center, Federal University of Santa \\ Catarina-UFSC, Campus Trindade, 88040-900, Florianópolis-SC, Brazil
}

*marieli@ufu.br

(Recebido em 11 de junho de 2020; aceito em 01 de outubro de 2020)

\begin{abstract}
The turkey neck is a cut with a higher proportion of meat when compared to the neck of other poultry, abundant in red fibers and is little valued by the food industry. It is possible to add value to this by-product through dry salting, an inexpensive and suitable method for the production of dried meat products, such as charqui. Turkey neck meat was submitted to the dry salting under different temperatures for study their salt gain and water loss on the flat plate geometry, using derived equations of Fick's Law, beyond the influence of the process in the physicochemical characteristics. The highest water loss $(33.99 \%)$ occurred at $10{ }^{\circ} \mathrm{C}$, while the highest salt gain $(9.47 \%)$ was observed at $15^{\circ} \mathrm{C}$. The empirical model presented a good fit to the experimental data. Apparent diffusivities were between $1.02 \times 10^{-10} \mathrm{~m}^{2} / \mathrm{s}$ and $1.18 \times 10^{-10} \mathrm{~m}^{2} / \mathrm{s}$. The dry salting promoted small decrease in $\mathrm{pH}$, the darkening of the meat, while shear force increased. After the process, water activity (aw) was 0.74 and 0.79 , moisture between $40.14 \%$ and $45.97 \%$, and ash residue $(12.30 \%$ $14.03 \%$ ), which characterizes a salt product with similar characteristics of charqui meat. It is possible to estimate the desirable amount of salt, producing a stable food product with a high conservation potential and a wide range of applications for derived salty products.

Keywords: poultry meat, charqui, apparent diffusivity
\end{abstract}

O pescoço de peru é um corte com alta proporção de carne quando comparado ao pescoço de outras aves, rico em fibras vermelhas e pouco valorizado pela indústria de alimentos. É possível agregar valor a este coproduto através da salga seca, um método barato e viável para a produção de produtos cárneos desidratados, como o charque. A carne de pescoço de peru foi submetida à salga seca sob temperaturas distintas para estudar o seu ganho de sal e a perda de água em geometria de placa plana, usando as equações derivadas da Lei de Fick, além da influência do processo nas características físico-químicas. Os valores mais altos de perda de água $(33,99 \%)$ ocorreram a $10{ }^{\circ} \mathrm{C}$, enquanto o ganho de sal mais alto $(9,47 \%)$ foi observado a $15{ }^{\circ} \mathrm{C}$. $\mathrm{O}$ modelo empírico apresentou um bom ajuste aos dados experimentais. As difusividades aparentes estiveram entre $1,02 \times 10^{-10} \mathrm{~m}^{2} / \mathrm{s}$ and $1,18 \times 10^{-10} \mathrm{~m}^{2} / \mathrm{s}$. A salga seca promoveu pequena redução no $\mathrm{pH}$, o escurecimento da carne, enquanto a força de cisalhamento aumentou. Após o processo, a atividade de água (aw) foi 0,74 e 0,79 , umidade entre $40,14 \%$ e $45,97 \%$ e o resíduo por cinzas (12,30\% -14,03\%), que caracteriza um produto salgado com características similares ao charque. É possível estimar a quantidade desejável de sal, produzindo um produto alimentício estável com um alto potencial de conservação e uma ampla variedade de aplicações para produtos salgados derivados.

Palavras-chave: carne de aves, charque, difusividade aparente

\section{INTRODUCTION}

Turkey meat consumption has been linked to its nutritional value because its low cuts (breast, wing, thigh, and drumstick) have high protein content (between 19.42\% until 20.84\%), low lipid content (1.5\% until $3.77 \%)$ and low calorie, what contributes with a healthy diet [1,2]. Among the turkey cuts, it is observed that the neck is little valued. It is darker meat, characterized by a higher proportion of red fibers in the muscle, being a product commercialized at a low value [3]. However, due to the higher meat proportion when compared with the neck of other poultry, makes it possible to use the turkey neck in other ways. 
The salted meat products are obtained through meat from butcher animals, boned or not, treated with salt, whether or not added with curing salts, seasoned or not, cooked or not [4]. The dried meat, sun-dried meat, and jerked beef are quite appreciated in several places in the world, especially in Brazil. In addition to being an important protein source obtained from less noble meat cuts, which result in a stable product with water activity around $0.75[5,6,7]$ which is an exciting proposal for the turkey neck meat.

The mathematical modeling application in the dry salting offers essential parameters for the industrial processes. Some parameters, such salt gain, and water loss determination, evaluation of the influence of ideal temperature in the process to obtain a product with adequate salt content are essential to characterize the dry salting, as observed in other researches $[7,8,9,10,11]$. The empirical model proposed by Azuara et al. (1992) [12], has been widely used to describe the dehydration rate in various plant and animal foods [13] and estimate the equilibrium concentration of solutes in beef [14], chicken breast meat [10], fish [15, 16] submitted to the different osmotic solutions.

The mass transfer that occurs during the dry salting can be studied based on the cellular structure of the material, modeling the water transport according to irreversible thermodynamic processes, or through the analytical solution of Fick's Second Law for diffusion in solids of different geometries. In the latter case, it is possible to estimate the diffusion coefficient for both water and solutes involved in the process, which is the approach proposed for this work [11, 17, 18, 19, 20].

The aim of this work was to study the kinetics of salt gain and water loss by dry salting in turkey neck meat through the effect of temperature, in addition to determining the apparent diffusion coefficient of salt in the meat, and to characterize the change in $\mathrm{pH}$, color, texture, moisture and ash content of turkey neck meat during the process.

\section{MATERIAL AND METHODS}

\subsection{Chemical analysis}

The centesimal composition was evaluated in the turkey neck meat. Moisture, ash, lipid, and protein contents were measured by AOAC methods [21]. Moisture content was determined by drying $5 \mathrm{~g}$ of minced meat in an oven at $105^{\circ} \mathrm{C}$. Ash content was determined by heating the residue for $3 \mathrm{~h}$ at $550{ }^{\circ} \mathrm{C}$. Protein content was determined by the Kjeldahl method. Lipid content was determined using the Soxhlet extraction method. Carbohydrate content was calculated by difference.

\subsection{Sample preparation and dry salting process}

Frozen turkey neck was subjected to thawing at $5{ }^{\circ} \mathrm{C}$ and boned manually with scalpels and cut into standard pieces in the flat plate format $(3.6 \mathrm{~cm} \times 6.0 \mathrm{~cm} \times 4.6 \mathrm{~cm})$. Dry salting was performed using commercial course-grained sodium chloride in the turkey meat cuts in the experimental apparatus built with an adaptation of the proposed by Sabadini et al. (1998) [20]. Samples were positioned on a support screen, to guarantee the unidirectional mass transfer in meat cuts, which were arranged with a bottom face in contact with the salt bed (5mm thick). A PVC film that recovered an upper face to prevent dehydration made isolation of the samples from the environment.

Dry salting was conducted at $10^{\circ} \mathrm{C}, 15^{\circ} \mathrm{C}, 20^{\circ} \mathrm{C}$, and $30^{\circ} \mathrm{C}$ for 96 hours. The experimental device with the samples was placed inside an incubator chamber with controlled temperature (BOD Tecnal TE-371) to maintain each of the test temperatures. Sampling for moisture measurement was carried out at $0,2,4$, and 6 hours at the beginning of the experiment, and within 12 hours until the end of the process. 


\subsection{Water loss and salt gain during dry salting}

The water loss (WL) and salt gain (SG) in the salted turkey neck meat were calculated according to Schmidt, Carciofi and Laurindo (2008) [10] and Azuara et al. (1992) [12]. Treated meat samples were removed from the apparatus, and the excess salt was removed from the sample by washing with distilled water and drying with paper towels. These samples were then weighed, crushed, and analyzed to determine their moisture [21] and $\mathrm{NaCl}$ concentrations by the Mohr method [21]. All analyses were performed in triplicate.

Equations 1 and 2 were used to calculate the WL and SG, respectively:

$$
\begin{aligned}
& \mathrm{WL}=\frac{\mathrm{m}_{\mathrm{a}}-\mathrm{m}_{\mathrm{a} 0}}{\mathrm{~m}_{0}} \times 100 \\
& \mathrm{SG}=\frac{\mathrm{m}_{\mathrm{s}}-\mathrm{m}_{\mathrm{s} 0}}{\mathrm{~m}_{0}} \times 100
\end{aligned}
$$

where $\mathrm{m}_{\mathrm{a}}$ is the water content in the sample at time $t, \mathrm{~m}_{\mathrm{a} 0}$ is the initial water content in the sample, $\mathrm{m}_{0}$ is the initial mass of the sample, $\mathrm{m}_{\mathrm{s}}$ is the salt mass in the sample at time $\mathrm{t}, \mathrm{m}_{\mathrm{s} 0}$ is the initial salt mass in the sample.

The fitting to the experimental data of water loss and/or gain (WL/WG). Solids gain (SG) was performed by the Azuara et al. (1992) [12] model (Equation 3), in the linearized form [10] to determine the $\mathrm{NaCl}$ concentration in the turkey neck meat in the equilibrium:

$$
\frac{\mathrm{t}}{\mathrm{SG}}=\frac{1}{\mathrm{k}\left(\mathrm{SG}^{\infty}\right)}+\frac{\mathrm{t}}{\mathrm{SG}^{\infty}}
$$

Similarly, Equation (3) can be written for water loss. The statistical parameters used to evaluate the models were the correlation coefficient $\left(\mathrm{R}^{2}\right)$, calculated based on the difference between the predicted gain or loss with the experimental value.

\subsection{Apparent salt diffusivity in turkey neck meat}

The apparent salt diffusivity was determined to employ an iterative process using the analytical solution of the mass conservation equation with the diffusive contribution of the Fick Law to infinite flat plate according to Equation (4). For $\mathrm{D}_{\mathrm{ap}}$ estimation, it was considered that salt concentration in the equilibrium was the final concentration after the dry salting process.

$$
\frac{C-C_{0}}{C_{e p}-C_{0}}=\frac{8}{\pi^{2}} \sum_{n=0}^{\infty} \frac{1}{(2 n+1)^{2}} \exp \left(\frac{-\mathcal{D}_{a p}(2 n+1)^{2} \pi^{2} t}{4 L^{2}}\right)
$$

$C_{i}$ value is the solution of Equation (4), where $\mathrm{C}$ is the concentration of component $\mathrm{A}$ in the time $\mathrm{t}$, $\mathrm{C}_{0}$ is the initial concentration and $\mathrm{C}_{\mathrm{eq}}$ is the concentration in the equilibrium and $\mathrm{L}$ is the characteristic dimension of the plate, it is assumed that in the contours of the plate $(x= \pm L)$, the concentration is the equilibrium concentration.

MATLAB® software (R2013a, MathWorksInc, MA, USA) was used to program the leastsquares methods to minimize the Dap, as a stopping criterion, the error was used in the $10^{-6}$ space. The statistical parameter used for the model evaluation was the correlation coefficient.

\subsection{Physicochemical analysis}

The turkey neck meat physicochemical properties were evaluated during the dry salting process $(0,2,4,6,12,24,48,72 \mathrm{e} 96 \mathrm{~h})$ for moisture, $\mathrm{pH}$, water activity, ashes, and instrumental color. In contrast, instrumental texture was performed before and after the dry salting. 
The AOAC methods [21] were used to determine moisture and ash content. $\mathrm{pH}$ was performed by direct reading in digital $\mathrm{pHmeter}$ (Quimis, Diadema-SP, Brazil).

The water activity was determined at the equipment Aqualab Model 3 Series (Decagon Devices Inc., Pullman, WA, USA). The instrumental color was performed in Minolta colorimeter model CR-400 (Konica Minolta, USA). The global change $(\Delta \mathrm{E})$, which is a numerical value that is used for the difference among the parameters $\mathrm{L}^{*}, \mathrm{a}^{*}$, and $\mathrm{b}^{*}$ of the standard measure in space, was determined through Equation (5).

$$
\Delta E=\sqrt{\left(\Delta \mathrm{L}^{*}\right)^{2}+\left(\Delta \mathrm{a}^{*}\right)^{2}+\left(\Delta \mathrm{b}^{*}\right)^{2}}
$$

Shear force $(\mathrm{N})$ was determined using a texturometer (TAXT Plus model, Stable Micro Systems) equipped with Warner Bratzler Shear Force (WBSP) probe.

All experiments were replicated three times. The data from physicochemical characterization of the salted turkey neck meat were evaluated by one-way ANOVA using Statistica ${ }^{\circledR}$ software (version 13.0). A post-hoc analysis was performed using Tukey test to evaluated difference among treatments at $\mathrm{p}<0.05$.

\section{RESULTS AND DISCUSSION}

\subsection{Chemical composition of turkey neck meat}

Turkey neck meat presented moisture content below other meat products $(69.41 \mathrm{~g} \pm 0.33 \mathrm{~g}$ of water/100 g sample, on wet basis). This value is little that moisture for other turkey cuts, such as leg $(74.87 \%$ and $75.04 \%)$ and breast $(73.23 \%$ and $74.9 \%)$ [1,22]. Lipid content found was $6.45 \pm$ $0.24 \%$, superior to the chicken neck (3.60\%) [23] and close to the found by Torres et al. (2000) [22] for Turkey leg cut $(7.43 \%)$. Protein value was $22.29 \% \pm 0.3 \%$, close to the protein content of the Turkey wing $(23.98 \%)$, and the Turkey breast $(24.80 \%)$, which suggests that this cut is an excellent protein source. Ash content found was $0.97 \pm 0.02 \%$, within the range found by Torres et al. (2000) [22] for the Turkey breast and leg (1.12\% and $0.93 \%$, respectively) and by Barbin et al. (2020) [1] for both Turkey breast and leg (1.13\%). Zapata et al. (1998) [24] describe that darker cuts (chicken leg) are more abundant in calcium, iron, sodium, and zinc, and weaker in phosphorus, magnesium, and potassium when compared to light cuts (breast). NIFEXT fraction calculation presented a value of $0.88 \%$ (dashes) for the carbohydrate present in the turkey neck. This value matches carbohydrate contents found for the Turkey leg (0.81\%) by Barbin et al. (2020) [1].

\subsection{Water loss and salt gain during dry salting process}

The dry salting process promoted the meat water diffusion to the external, while the salt diffuses inside the meat matrix and was quantified in terms of water loss and salt gain during the period. Figures $1 \mathrm{a}$ and $1 \mathrm{~b}$ show the water loss and salt gain during the dry salting period, determined by Equations (1) and (2), respectively.

Turkey neck meat presented an increase of variation in the water loss (WL) during the dry salting. The difference between WL among the temperatures tested was $28.01 \%$ to $33.99 \%$. The most water loss was at $2 \mathrm{~h}$ of the process for all samples. This mechanism is expected, because since at the beginning of salting the concentration of saline on the surface of the meat pieces is higher, or that results in a more significant release of water, besides that the gradient of concentration between salt course and the meat is higher [25, 26, 27]. However, WL in this period ( 2 hours) was inversely proportional to the dry salting temperature. Lower WL was at $30{ }^{\circ} \mathrm{C}$ (4.97\%), and the higher WL occurred at $10{ }^{\circ} \mathrm{C}(12.11 \%)$, an opposite behavior when compared with other studies that observed the temperature effect during osmotic dehydration [16, 28, 29, 30]. After the dry salting process, WL was higher at $10{ }^{\circ} \mathrm{C}(33.99 \%)$ when compared to the other temperatures, while WL was lower at $15^{\circ} \mathrm{C}(23.31 \%)$. However, the diffusion properties can also be influenced by the muscle and tissue orientation, with the anisotropic behavior of salt diffusion 
in muscle, as noted by Zhang et al. (2011) [31]. In Turkey's neck, the muscle and connective tissue are distributed around the bone (like a cylinder), while the deboned neck took the shape of a flat plate. Besides that, other factors, such as species and fat content in the muscle can influence the diffusion mechanism, especially in turkey neck, the lipid distribution into the meat tissue and the lipid content (6.45\%, presented previously) besides containing a high proportion of connective tissue (collagen and subcutaneous, inter and intracellular fat).

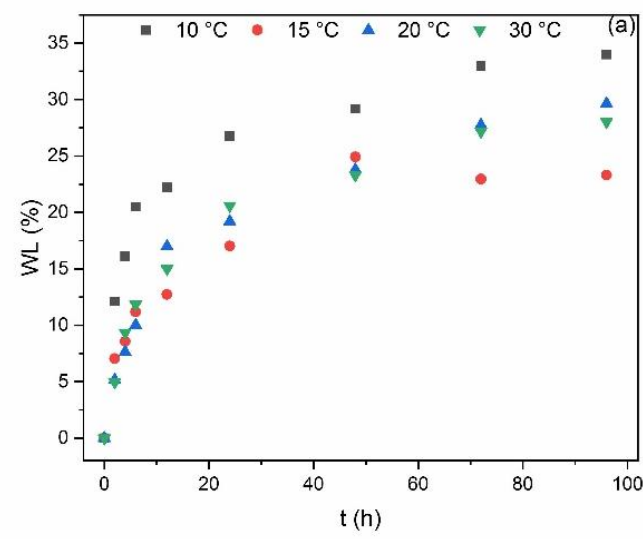

(a)

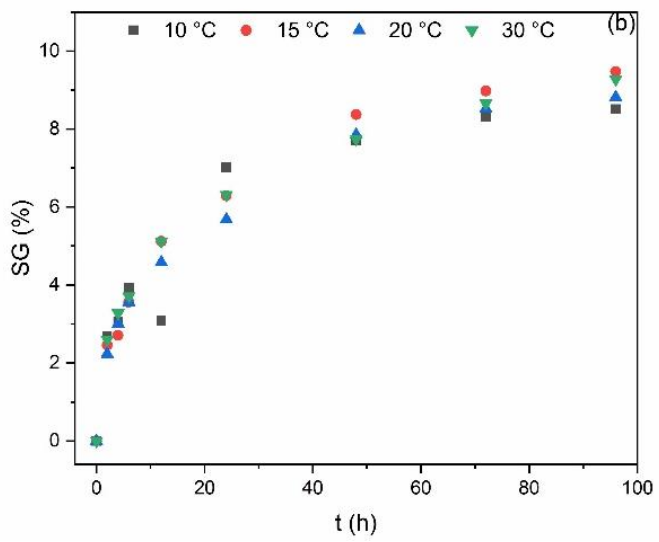

(b)

Figure 1: Water loss (WL) during the dry salting of turkey neck meat (a) and salt gain (SG) during the dry salting of turkey neck meat (b).

The salt gain in the turkey neck meat was growing, and the salt concentration after the process had little variation among temperatures tested $(8.51 \%$ to $9.47 \%)$. In the first 2 hours, occurred the most salt gain (2.23\% until $2.69 \%)$, where the concentration gradient at the beginning of the process is higher, and diffusion tends to decreases until the equilibrium [32]. Comparing the salt gain during each 24 hours, it was possible to observe that the most increase occurred during the first 24 hours of dry salting $(7.02 \% ; 6.29 \% ; 5.68 \%$ and $6.31 \%)$. This effect is due to the high osmotic pressure that the Turkey neck meat was exposed, according to described by Turan et al. (2007) [33] in mussels, such as the first stage of salting. After this, from $48 \mathrm{~h}$ until $72 \mathrm{~h}$, there was a slower increasing, which characterizes that the rate of salt intake into the turkey neck or the water loss from the meat does not have vast difference (second salting step also showed by Turan et al. (2007) [33] and finally, between $72 \mathrm{~h}$ and $96 \mathrm{~h}$ occurred the third salting step, with the minor quantity of salt into the turkey meat.

The variation in salt gain observed among the temperature used during the dry salting could be influenced by some factors. The Turkey neck meat structure is abundant both in muscle and connective tissue, heterogeneously distributed through the meat. Martínez-Lopez, Bertelsen and Jessen (2019) [34] described differences in salt diffusion between the skin and the meat during dry salting of salmon and observed that the limit between the muscle and the skin is permeable until salt to reach the saturation point and the flux is interrupted and until the system arrives at stationary state. Thus, in this work could be occurred the similar effect described by these authors, which suggested that salt intake at different rates both the skin and the muscle interfaces. Another factor related to the meat composition is the lipid content, in which Turkey neck meat presented $6.45 \pm$ $0.24 \%$, which could be influenced also by the salt intake in different treatments. Czerner and Yeannes (2013) [35] verified that the initial lipid content in fish influenced inversely on mass transfer kinetics, that is, when the initial lipid content increases, the salt gain rate decreases. The Turkey neck meat presented a little variation of lipid content, but the fat tissue usually is heterogeneously distributed and could be influenced in the salt intake during the treatments tested.

The experimental data were applied to the empirical model of Azuara et al. (1992) [12]. Table 1 presents the values of water loss and salt gain and in equilibrium, the $\mathrm{K}_{\mathrm{w}}$ and $\mathrm{K}_{\mathrm{s}}$ constant, determined by the Equation (3), in addition to the correlation coefficient $\left(\mathrm{R}^{2}\right)$. 
The salt gain and the water loss presented proper fitting to the experimental data, with $\mathrm{R}^{2}>0.968$ for all fitting, except for the salt gain during the dry salting at $\mathrm{T}=30{ }^{\circ} \mathrm{C}$, which obtained the lowest $\mathrm{R}^{2}$ (0.9032). Other authors also obtained good fitting. Schmidt, Carciofi and Laurindo (2008) [10] studied the osmotic dehydration process chicken breast and obtained a good fitting of the model to the experimental data for water loss and salt gain with Azuara et al. (1992) [12]. The empirical model also showed an excellent proper fitting for pile salting of goat sheets [36] and the osmotic vacuum dehydration of mapará fillets [29].

Table 1: Parameters estimated by Azuara's model, statistical fit parameters, and apparent diffusivity - Dap $\left(\mathrm{m}^{2} / \mathrm{s}\right)$.

\begin{tabular}{|c|c|c|c|c|c|c|c|c|}
\hline & \multicolumn{3}{|c|}{ Water Loss } & \multicolumn{3}{|c|}{ Salt gain } & \multicolumn{2}{|c|}{ Apparent diffusivity } \\
\hline $\begin{array}{l}\text { Dry salting } \\
\text { temperature }\end{array}$ & $\begin{array}{r}\mathrm{M} \\
\text { para }\end{array}$ & $\begin{array}{l}\text { del } \\
\text { eters }{ }^{a}\end{array}$ & $\begin{array}{l}\text { Correlation } \\
\text { coefficient }^{\mathrm{b}}\end{array}$ & $\begin{array}{r}\mathrm{M} \\
\text { paran }\end{array}$ & $\begin{array}{l}\text { del } \\
\text { eters }{ }^{a}\end{array}$ & $\begin{array}{l}\text { Correlation } \\
\text { coefficient }\end{array}$ & $\begin{array}{l}\text { Fick's } \\
\text { Law }\end{array}$ & $\begin{array}{l}\text { Correlation } \\
\text { coefficient }\end{array}$ \\
\hline$\left({ }^{\circ} \mathrm{C}\right)$ & $W L^{\infty}$ & $\mathrm{K}_{\mathrm{w}}$ & $\mathrm{R}^{2}$ & $S G^{\infty}$ & $\mathrm{K}_{\mathrm{s}}$ & $\mathrm{R}^{2}$ & $\operatorname{Dap}\left(\mathrm{m}^{2} / \mathrm{s}\right)$ & $\mathrm{R}^{2}$ \\
\hline 10 & 34.72 & 261.7 & 0.993 & 9.160 & 9.996 & 0.968 & $1.18 \times 10^{-10}$ & 0.944 \\
\hline 15 & 25.07 & 98.52 & 0.986 & 10.080 & 11.570 & 0.986 & $1.02 \times 10^{-10}$ & 0.993 \\
\hline 20 & 31.65 & 95.65 & 0.981 & 9.406 & 10.390 & 0.984 & $1.03 \times 10^{-10}$ & 0.989 \\
\hline 30 & 5.17 & 0.427 & 0.873 & 15.86 & 4.024 & 0.9032 & $1.06 \times 10^{-10}$ & 0.989 \\
\hline
\end{tabular}

aarameters estimated by model from Azuara et al. [12]: water loss in the equilibrium $\left(\mathrm{WL}^{\infty}\right.$ in $\left.\mathrm{g} / 100 \mathrm{~g}\right)$ and $\mathrm{k}$ constant; and ${ }^{\mathrm{b}}$ correlation coefficient $\left(\mathrm{R}^{2}\right){ }^{\mathrm{b}}$ statistical parameters by model from Azuara et al. [12] to the experimental data.

The $\mathrm{k}$ constant makes it possible to evaluate the rate in which the process reached the equilibrium. So, the higher is the $\mathrm{k}$ value, the higher is the mass diffusion, whether for water loss or salt gain, for time. The results show there was little difference for $\mathrm{K}_{\mathrm{w}}$ and $\mathrm{K}_{\mathrm{s}}$ at $10{ }^{\circ} \mathrm{C}, 15^{\circ} \mathrm{C}$ and $20{ }^{\circ} \mathrm{C}$. However, the temperature seems to have to affect $\mathrm{K}_{\mathrm{w}}$ and $\mathrm{K}_{\mathrm{s}}$ at $30{ }^{\circ} \mathrm{C}$, respectively. Thus, the increase in temperature decreased the diffusion of water out of the meat, while the increase in temperature from $10{ }^{\circ} \mathrm{C}$ to $15^{\circ} \mathrm{C}$ and $20^{\circ} \mathrm{C}$ favored the salt gain.

\subsection{Sodium chloride apparent diffusivity}

The sodium chloride apparent diffusion coefficient determined for each salting temperature using the analytical solution of Fick's Law for the infinite flat plate are shown in Table 1, with the correlation coefficient, $\mathrm{R}^{2}$. The values showed little variation with the temperature $\left(1.02 \times 10^{-10}\right.$ $\mathrm{m}^{2} / \mathrm{s}$ to $\left.1.18 \times 10^{-10} \mathrm{~m}^{2} / \mathrm{s}\right)$. This range of Dap is within the order of magnitude $\left(1 \times 10^{-10} \mathrm{~m}^{2} / \mathrm{s}\right)$ reported in the literature for salt diffusion in meat products. Schmidt, Carciofi and Laurindo (2009) [18] found salt diffusivity values in chicken breast varying among $2.5 \times 10^{-10} \mathrm{~m}^{2} / \mathrm{s}$ and $2.9 \times 10^{-10}$ $\mathrm{m}^{2} / \mathrm{s}$. Volpato et al. (2007) [11] studied the interference of $\mathrm{NaCl}$ and phosphate concentration in brine and the process temperature for osmotic dehydration in chicken breasts, obtaining diffusivities among $8.99 \times 10^{-10} \mathrm{~m}^{2} / \mathrm{s}$ to $9.55 \times 10^{-10} \mathrm{~m}^{2} / \mathrm{s}$. Telis et al. (2003) [19] studied the wet salting of caiman meat from the Pantanal in different salt concentrations and under different temperatures and found values from $4.7 \times 10^{-9}$ to $9.62 \times 10^{-10} \mathrm{~m}^{2} / \mathrm{s}$. Corzo, Bracho and Rodríguez (2013) [37] evaluated the pile salting of goat meat slices and found $D_{a p}$ values from $1.66 \times 10^{-10}$ $\mathrm{m}^{2} / \mathrm{s}$ to $2.44 \times 10^{-10} \mathrm{~m}^{2} / \mathrm{s}$. Chabbouh et al. (2012) [17] evaluated the wet and drying salting in Kaddid Meat and found values among $4.081 \times 10^{-10} \mathrm{~m}^{2} / \mathrm{s}$ and $8.075 \times 10^{-10} \mathrm{~m}^{2} / \mathrm{s}$. The differences among the studies are due to the factors that influence the water and salt diffusion, such muscle and tissue orientation, shrinkage effect, product size and geometry, temperature, salting method, the direction of the diffusion process, local molality, mathematical or empiric methods for diffusion calculation and solution/solute-to-material ratio [17, 34]. 


\subsection{Physicochemical changes during the dry salting kinetics}

Table 2 shows the $\mathrm{pH}$ for Turkey's neck meat during dry salting. The raw meat presented $\mathrm{pH}$ among $5.99 \pm 0.09$ and $6.45 \pm 0.02$ for all the treatments. This variation on $\mathrm{pH}$ also was observed by Chan, Omana and Betti (2011) [38] that classified the pH after 24 hours of slaughtering of turkey breast meat as low, average, and high $\mathrm{pH}$ meat due to the occurrence of PSE (pale, soft and exudative), standard or DFD (dark, firm and dry). Turkey meat $\mathrm{pH}$ also have more value than other poultry meat because the higher red fibers concentrated in the neck than the breast, which is rich in white fibers.

Since anaerobic metabolism is higher in white fibers than in red fibers, tissues rich in red fibers use less post-mortem acidification than tissues rich in white fibers. Takahashi et al. (2012) [39] showed $\mathrm{pH}$ values in the breast of four different lines of chickens with different ages between 5.64 and 5.92, while the $\mathrm{pH}$ for a leg of the same lines was between 6.04 and 6.17. However, no studies were found that relate to the $\mathrm{pH}$ of the turkey neck meat.

During the dry salting, $\mathrm{pH}$ increased $0.17 \mathrm{pH}$ units at $10{ }^{\circ} \mathrm{C}$. However, this little change was not significative $(\mathrm{p}>0.05)$. For the other temperatures, $\mathrm{pH}$ presented a little and significative $(\mathrm{p}>0.05)$ decrease $(0.17$ to $0.37 \mathrm{pH}$ units). After $96 \mathrm{~h}$ of dry salting, $\mathrm{pH}$ presented range among $5.98 \pm 0.020$ and 6.16 \pm 0.04 . This behavior shows that the $\mathrm{pH}$ was more affected significantly $(\mathrm{p}<0.05)$ in the first two hours of dry salting for the temperatures of $15^{\circ} \mathrm{C}$ and $20^{\circ} \mathrm{C}$, a period in which the most considerable salt diffusion occurred, which interferes with the solubilization of myofibrillar proteins, causing changes in the $\mathrm{pH}$ due to the interference in the isoelectric point of the meat proteins. For the drying salting temperature of $30^{\circ} \mathrm{C}$, the significative reduction of $\mathrm{pH}$ occurred after $12 \mathrm{~h}$ of process. Temperature of the drying salting presented significative influence on the $\mathrm{pH}$ $(\mathrm{p}<0.05)$ only after $12 \mathrm{~h}$ of process for treatments under $20^{\circ} \mathrm{C}$ and $30^{\circ} \mathrm{C}$; while drying salting under $10{ }^{\circ} \mathrm{C}$ presented significative difference compared with other temperatures after $24 \mathrm{~h}$. The samples salted under $30^{\circ} \mathrm{C}$ presented significative difference to other treatments after $48 \mathrm{~h}$ of process.

Arnau, Guerrero and Gou (1997) [40] evaluated three salting times and three different temperatures $\left(20,25\right.$ and $\left.30^{\circ} \mathrm{C}\right)$ in dry cured ham and observed that the higher temperature $\left(30{ }^{\circ} \mathrm{C}\right)$ increased the activity of proteases and also promoted a little decrease in $\mathrm{pH}$ and attributed to the phosphate losses stated and the salt uptake. Torres et al. (1988) [41] carried out the grinding and salting of beef after rigor mortis and observed that the application of salt in the meat caused the $\mathrm{pH}$ decline. Goli et al. (2011) [42] also verified a decrease of $\mathrm{pH}$ in the turkey meat submitted to the acidic marination. In this work, the decrease in $\mathrm{pH}$ was lower because the dry salting was conducted only with sodium chloride. There is no quality standard in the Brazilian Legislation for the $\mathrm{pH}$ of salty products. Garcia et al. (2013) [43] found for jerked beef a pH of 5.90. Assis et al. (2019) [44], reported $\mathrm{pH}$ values varying from 5.30 to 6.50 for several samples of commercial sun meat produced in Brazil.

The water activity (aw) variation during the dry salting is presented in Table 2 . A significative decrease $(\mathrm{p}=0.0318)$ occurred under the range from 0.99 until $(0.74-0.79)$ for all the treatments, showing influence of the temperature. In dry salting at $10^{\circ} \mathrm{C}$, the loss in water activity was significantly higher in the first $4 \mathrm{~h}$ of salting, due to the more significant concentration gradient already mentioned in this salting process. The dry salting period also promoted significative reduction in water activity $(\mathrm{p}<0.05)$ was more pronounced in all samples up to 72 hours of dry salting ( $\mathrm{p}<0.05)$, where in the last 24 hours aw reduced by only 0.01 units, except for salting at 20 ${ }^{\circ} \mathrm{C}$, which presented a lower aw (0.74) and reduction of 0.02 units. This smaller gradient at the end of the process may show the beginning of the osmotic balance of turkey neck meat. Sabadini et al. (2001) [45] carried out the dry salting of meat (M. trapezius) for $96 \mathrm{~h}$ and also verified lower water activity for the salting at $20^{\circ} \mathrm{C}(0.75)$ about the process carried out at $10{ }^{\circ} \mathrm{C}(0.79)$.

The final water activity for the desiccated neck remained between 0.74 to 0.79 . Brazilian law stipulates a maximum limit of 0.80 for water activity in charqui. Salvá et al. (2012) [46] found aw values for beef made from alpaca, between 0.30 and 0.73; Torres et al. (1994) [48] produced beef charqui from beef cuts with water activity ranging from 0.70 to 0.75 . 
Table 2: Physicochemical characteristics for Turkey neck meat at $10^{\circ} \mathrm{C}, 15^{\circ} \mathrm{C}, 20^{\circ} \mathrm{C}$ and $30^{\circ} \mathrm{C}$, during 96 hours.

\begin{tabular}{|c|c|c|c|c|c|c|c|c|c|}
\hline Dry salting period (h) & $\mathbf{0}$ & 2 & 4 & 6 & 12 & 24 & 48 & 72 & 96 \\
\hline Temperature $\left({ }^{\circ} \mathbf{C}\right)$ & & & & & pH & & & & \\
\hline 10 & $5.99 \pm 0.09 \mathrm{aA}$ & $5.97 \pm 0.18 \mathrm{aA}$ & $6.24 \pm 0.06 \mathrm{aA}$ & $6.21 \pm 0.13 \mathrm{aA}$ & $6.10 \pm 0.09 \mathrm{abA}$ & $6.20 \pm 0.02 \mathrm{aA}$ & $6.09 \pm 0.03 \mathrm{aA}$ & $6.04 \pm 0.11 \mathrm{aA}$ & $6.16 \pm 0.04 \mathrm{aA}$ \\
\hline 15 & $6.40 \pm 0.05 \mathrm{bA}$ & $6.12 \pm 0.11 \mathrm{aBC}$ & $6.11 \pm 0.05 \mathrm{aBC}$ & $6.16 \pm 0.06 \mathrm{aB}$ & $6.10 \pm 0.03 \mathrm{abBC}$ & $6.08 \pm 0.02 \mathrm{abBC}$ & $6.12 \pm 0.02 \mathrm{aBC}$ & $6.01 \pm 0.03 \mathrm{aBC}$ & $6.11 \pm 0.04 \mathrm{aC}$ \\
\hline 20 & $6.45 \pm 0.02 \mathrm{bA}$ & $6.19 \pm 0.04 \mathrm{aB}$ & $6.11 \pm 0.02 \mathrm{aBC}$ & $6.05 \pm 0.02 \mathrm{aC}$ & $6.12 \pm 0.02 \mathrm{aBC}$ & $5.94 \pm 0.09 \mathrm{bD}$ & $6.12 \pm 0.02 \mathrm{aBC}$ & $6.04 \pm 0.01 \mathrm{aCD}$ & $6.08 \pm 0.02 \mathrm{aC}$ \\
\hline 30 & $6.15 \pm 0.02 \mathrm{cA}$ & $6.14 \pm 0.06 \mathrm{aA}$ & $6.13 \pm 0.05 \mathrm{aA}$ & $6.12 \pm 0.04 \mathrm{aAB}$ & $5.94 \pm 0.08 \mathrm{bC}$ & $6.01 \pm 0.05 \mathrm{bABC}$ & $5.93 \pm 0.04 \mathrm{bC}$ & $5.88 \pm 0.06 \mathrm{aC}$ & $5.98 \pm 0.02 \mathrm{bBC}$ \\
\hline Temperature $\left({ }^{\circ} \mathbf{C}\right)$ & \multicolumn{9}{|c|}{ Water Activity (aw) } \\
\hline 10 & $0.97 \pm 0.01 \mathrm{aA}$ & $0.95 \pm 0.01 \mathrm{aAB}$ & $0.89 \pm 0.06 \mathrm{aBD}$ & $0.88 \pm 0.03 \mathrm{aD}$ & $0.91 \pm 0.01 \mathrm{aABD}$ & $0.85 \pm 0.02 \mathrm{aDE}$ & $0.81 \pm 0.01 \mathrm{aCE}$ & $0.77 \pm 0.01 \mathrm{aC}$ & $0.76 \pm 0.01 \mathrm{aC}$ \\
\hline 15 & $0.99 \pm 0.00 \mathrm{bA}$ & $0.96 \pm 0.01 \mathrm{bAB}$ & $0.96 \pm 0.01 \mathrm{aBD}$ & $0.92 \pm 0.01 \mathrm{abD}$ & $0.88 \pm 0.03 \mathrm{abABD}$ & $0.85 \pm 0.01 \mathrm{aDE}$ & $0.79 \pm 0.00 \mathrm{abCE}$ & $0.78 \pm 0.01 \mathrm{aC}$ & $0.79 \pm 0.00 \mathrm{bC}$ \\
\hline 20 & $0.99 \pm 0.01 \mathrm{bA}$ & $0.97 \pm 0.01 \mathrm{cAC}$ & $0.94 \pm 0.01 \mathrm{aC}$ & $0.94 \pm 0.01 \mathrm{bC}$ & $0.86 \pm 0.02 \mathrm{abB}$ & $0.84 \pm 0.01 \mathrm{abB}$ & $0.77 \pm 0.02 b D$ & $0.76 \pm 0.01 \mathrm{aD}$ & $0.74 \pm 0.00 \mathrm{cD}$ \\
\hline 30 & $0.99 \pm 0.00 \mathrm{bA}$ & $0.97 \pm 0.01 \mathrm{cB}$ & $0.95 \pm 0.00 \mathrm{aBC}$ & $0.93 \pm 0.00 \mathrm{bC}$ & $0.87 \pm 0.00 \mathrm{bD}$ & $0.81 \pm 0.01 \mathrm{bE}$ & $0.77 \pm 0.00 \mathrm{bF}$ & $0.77 \pm 0.00 \mathrm{aF}$ & $0.76 \pm 0.00 \mathrm{aF}$ \\
\hline Temperature $\left({ }^{\circ} \mathbf{C}\right)$ & \multicolumn{9}{|c|}{ Moisture in wet basis (\%) } \\
\hline 10 & $70.80 \pm 0.62 \mathrm{aA}$ & $64.52 \pm 0.33 \mathrm{acB}$ & $61.57 \pm 1.41 \mathrm{aB}$ & $58.12 \pm 2.22 \mathrm{aC}$ & $56.58 \pm 1.80 \mathrm{aC}$ & $50.76 \pm 0.47 \mathrm{aD}$ & $49.13 \pm 0.08 \mathrm{aD}$ & $41.76 \pm 0.99 \mathrm{abE}$ & $41.93 \pm 0.20 \mathrm{aE}$ \\
\hline 15 & $69.09 \pm 0.11 \mathrm{bA}$ & $61.91 \pm 0.27 \mathrm{bB}$ & $60.83 \pm 0.19 \mathrm{aBC}$ & $57.93 \pm 2.43 \mathrm{aCD}$ & $56.50 \pm 1.30 \mathrm{aD}$ & $51.72 \pm 1.40 \mathrm{aE}$ & $43.82 \pm 0.74 \mathrm{bF}$ & $46.26 \pm 0.91 \mathrm{cF}$ & $45.97 \pm 0.85 \mathrm{bF}$ \\
\hline 20 & $68.55 \pm 0.78 \mathrm{bA}$ & $63.60 \pm 0.85 \mathrm{cB}$ & $61.48 \pm 1.17 \mathrm{aBC}$ & $59.12 \pm 0.48 \mathrm{aC}$ & $52.42 \pm 0.52 \mathrm{bD}$ & $49.89 \pm 0.64 \mathrm{aD}$ & $45.04 \pm 2.09 \mathrm{bcE}$ & $41.65 \pm 0.53 \mathrm{aF}$ & $40.14 \pm 1.86 \mathrm{aF}$ \\
\hline 30 & $71.13 \pm 0.00 \mathrm{aA}$ & $65.77 \pm 0.00 \mathrm{cB}$ & $61.53 \pm 0.00 \mathrm{aC}$ & $59.92 \pm 0.00 \mathrm{aC}$ & $56.21 \pm 0.00 \mathrm{aD}$ & $50.68 \pm 0.00 \mathrm{aE}$ & $47.93 \pm 0.00 \mathrm{cF}$ & $44.07 \pm 0.01 \mathrm{bcG}$ & $42.96 \pm 0.02 \mathrm{abG}$ \\
\hline Temperature $\left({ }^{\circ} \mathbf{C}\right)$ & \multicolumn{9}{|c|}{ Ash content $(\%)$} \\
\hline 10 & $1.00 \pm 0.03 \mathrm{aA}$ & $4.14 \pm 0.40 \mathrm{aB}$ & $5.84 \pm 1.27 \mathrm{aC}$ & $5.66 \pm 0.44 \mathrm{aC}$ & $7.04 \pm 0.73 \mathrm{aD}$ & $11.50 \pm 0.56 \mathrm{aE}$ & $13.07 \pm 0.43 \mathrm{aF}$ & $13.74 \pm 0.58 \mathrm{aF}$ & $14.03 \pm 0.30 \mathrm{aF}$ \\
\hline 15 & $0.95 \pm 0.03 \mathrm{aA}$ & $4.61 \pm 0.51 \mathrm{aB}$ & $5.13 \pm 0.25 \mathrm{aB}$ & $6.51 \pm 0.36 \mathrm{bBC}$ & $8.48 \pm 0.23 b C D$ & $10.84 \pm 0.25 \mathrm{aDE}$ & $13.05 \pm 0.50 \mathrm{aE}$ & $13.61 \pm 0.32 \mathrm{aE}$ & $12.30 \pm 5.74 \mathrm{aE}$ \\
\hline 20 & $1.02 \pm 0.06 \mathrm{aA}$ & $4.22 \pm 0.48 \mathrm{aB}$ & $5.46 \pm 0.24 \mathrm{aB}$ & $6.19 \pm 0.10 \mathrm{abBC}$ & $7.96 \pm 0.28 \mathrm{abCD}$ & $9.78 \pm 0.24 \mathrm{aD}$ & $12.80 \pm 3.62 \mathrm{aE}$ & $13.49 \pm 0.25 \mathrm{aE}$ & $13.84 \pm 1.05 \mathrm{aE}$ \\
\hline 30 & $1.05 \pm 0.00 \mathrm{aA}$ & $4.56 \pm 0.03 \mathrm{aB}$ & $5.48 \pm 0.06 \mathrm{aB}$ & $6.03 \pm 0.01 \mathrm{abBC}$ & $7.75 \pm 0.02 \mathrm{abCD}$ & $9.03 \pm 0.02 \mathrm{bDE}$ & $12.74 \pm 0.08 \mathrm{aEF}$ & $12.43 \pm 0.01 \mathrm{bEF}$ & $13.66 \pm 0.06 \mathrm{aF}$ \\
\hline Temperature $\left({ }^{\circ} \mathbf{C}\right)$ & \multicolumn{9}{|c|}{ Global color change $(\Delta E)$} \\
\hline 10 & 0 & $10.16 \pm 3.08 \mathrm{aA}$ & $9.84 \pm 3.28 \mathrm{aA}$ & $12.34 \pm 3.53 \mathrm{aA}$ & $12.08 \pm 6.57 \mathrm{aA}$ & $17.91 \pm 1.76 \mathrm{aA}$ & $17.17 \pm 3.80 \mathrm{aA}$ & $19.26 \pm 2.41 \mathrm{aA}$ & $18.51 \pm 3.87 \mathrm{aA}$ \\
\hline 15 & 0 & $7.32 \pm 1.20 \mathrm{aA}$ & $7.49 \pm 3.07 \mathrm{aA}$ & $8.14 \pm 1.54 \mathrm{aAB}$ & $9.51 \pm 0.28 \mathrm{aAB}$ & $11.37 \pm 1.07 \mathrm{aAB}$ & $9.94 \pm 1.56 \mathrm{aAB}$ & $12.09 \pm 2.91 \mathrm{aAB}$ & $13.38 \pm 1.73 \mathrm{aB}$ \\
\hline 20 & 0 & $11.05 \pm 0.49 \mathrm{aAB}$ & $10.34 \pm 0.87 \mathrm{aB}$ & $11.95 \pm 2.03 \mathrm{aAB}$ & $12.42 \pm 0.49 \mathrm{aAB}$ & $13.39 \pm 1.67 \mathrm{aAB}$ & $14.32 \pm 1.49 \mathrm{aAB}$ & $14.93 \pm 1.89 \mathrm{aA}$ & $14.53 \pm 2.14 \mathrm{aAB}$ \\
\hline 30 & 0 & $12.90 \pm 3.05 \mathrm{aA}$ & $12.81 \pm 4.25 \mathrm{aA}$ & $10.52 \pm 3.00 \mathrm{aA}$ & $14.90 \pm 2.06 \mathrm{aA}$ & $15.09 \pm 2.48 \mathrm{aA}$ & $11.80 \pm 0.90 \mathrm{aA}$ & $11.31 \pm 0.79 \mathrm{aA}$ & $12.97 \pm 3.23 \mathrm{aA}$ \\
\hline
\end{tabular}

Lowercase letters between lines differ on the temperature. Uppercase letters between columns differ on the dry salting period. $\mathrm{P}<0.05$. 
The sun meat goes through softer salting, which results in a product with higher water activity, around 0.92 , varying according to the processing techniques. The final water activity obtained for the salted turkey neck classifies the final product as charqui [26, 46, 47, 48].

The average of initial moisture (Table 2) was around $69.48 \pm 1.13 \%$; this value is slightly less than the moisture found by other studies, such as leg $(74.87 \%$ and $75.04 \%)$ and for breast $(73.23 \%$ and $74.9 \%)[1,22]$. This difference can be explained by the exudation of the turkey neck during thawing and deboning. The temperature of dry salting $(\mathrm{p}=0.004)$ influenced the moisture values in some periods of the process (except in $4 \mathrm{~h}, 6 \mathrm{~h}$ and $24 \mathrm{~h}$ ), while the period of the dry salting $(\mathrm{p}<0.05)$ influenced significantly in the moisture of the samples. It was observed that in the first hours, the moisture loss was more significant, stabilizing with the processing period, which demonstrates that the meat parts were tending to balance. After $72 \mathrm{~h}$ of salting, the moisture varied in the range of $1 \%$ (not significative $-\mathrm{p}>0.05$ ) for all treatments.

Biscontini et al. (1996) [49] presented a wet salting mechanism that explains the change that occurs in the tissue during the production of jerked beef. After the uniform distribution of salt through the tissue, swelling occurs by absorbing water from the brine to dilute the salt. Reaching $15 \%$ of the final salt concentration, band A is extracted, and myosin is unable to retain water. The depolymerization of the myosin, together with the osmotic pressure, favors the migration of water from the myofibrillar spaces to the interfibrillar spaces, going to the extracellular compartments and finally escaping to the meat surface. At the end of the process, the intercellular space shrinks, and the extracellular space increases, which favors the drainage of saline solutions. Dry salting did not involve initial water absorption, only loss as the results for water loss show throughout the process. The final moisture of the turkey neck after $96 \mathrm{~h}$ of salting was within limits established by Brazilian Legislation for charqui $\left(50 \%\right.$ on a wet basis), with a temperature of $15{ }^{\circ} \mathrm{C}$ having the highest value for moisture $(45.97 \pm 0.85 \%)$, while samples dried at $20^{\circ} \mathrm{C}$ showed lower moisture $(40.14 \pm 1.86 \%)[47]$.

The ash content in the raw turkey neck obtained in this work (Table 2) was within the range found by Torres et al. (2000) [22] for the turkey breast and leg (0.93 and 1.12\% respectively), in addition to the range found by Barbin et al. (2020) [1] for both Turkey breast and leg (1.13\%). It is noted that in the first $24 \mathrm{~h}$ of salting the meat absorbed the salt quickly, representing the significant increase $(\mathrm{p}<0.05)$ in ash that the samples had in that period. Upon reaching $48 \mathrm{~h}$ of salting, the ash content started to stabilize, indicating that the tissue was reaching balance in terms of water loss and salt gain [22]. In the general context, the temperature of dry salting did not influence the ash content. However, there were significative differences $(\mathrm{p}<0.05)$ for ash content between $10^{\circ} \mathrm{C}$ and $15^{\circ} \mathrm{C}$ at $12 \mathrm{~h} ; 30^{\circ} \mathrm{C}$ at $24 \mathrm{~h}$ and $72 \mathrm{~h}$, respectively. This little variation could be related to the salt gain during the dry salting process, as previously stated, the salt diffusion can be affected by the stage of the salting [32], nature and composition of the meat tissue [33, 34, 35]. The turkey neck after $96 \mathrm{~h}$ of salting showed $13.45 \%$ of fixed mineral residue (ash) for all treatments, where the Brazilian Legislation establishes a maximum limit of $23 \%$ for charqui [47].

The global color change $(\Delta \mathrm{E})$ is shown in Table 2. It was observed that the increase in temperature caused a not significant decrease $(p>0.05)$ in color variation after the process (mainly in the treatment at $30{ }^{\circ} \mathrm{C}$ ), while in the other evaluated salting temperatures, $\Delta \mathrm{E}$ was higher and increasing significantly $(\mathrm{p}<0.05)$ during the dry salting time $\left(\right.$ at $10{ }^{\circ} \mathrm{C}, 15^{\circ} \mathrm{C}$ and $\left.20^{\circ} \mathrm{C}\right)$. Thus, the temperature of the dry salting did not affect significantly the global change ( $>>0.05)$, except for the conditions $\left(15^{\circ} \mathrm{C} / 96 \mathrm{~h}\right.$ and $\left.20^{\circ} \mathrm{C} / 72 \mathrm{~h}\right)$. However statistically the color difference was not significative with the dry salting period for all treatments (at $10{ }^{\circ} \mathrm{C}$ and $30{ }^{\circ} \mathrm{C}$ ), this parameter increased proportionally with the concentration of salt in the process and also the fact of the samples analyzed are destructive, increased the standard deviation of the measurement, which influenced on the not significant differences. For all temperatures it was noted that in the last hours of salting there was a not significant slight variation in the values of $\Delta \mathrm{E}$ (between 0.14 to 1.29 units). Bampi, Schimidt and Laurindo (2019) [50] salted beef with reduced sodium content and found values of global color difference between 7.79 to 14.15 , in which the increase in the salt content used during the process promoted more considerable color change. Still in the study by Bampi, Schimidt and Laurindo (2019) [50], $\Delta \mathrm{E}$ values between 6.0 and 12.0 show a massive color difference, and above 12.0 units, the difference is classified as very large. 
This global variation is a result of the variations observed in the parameters $\mathrm{L}^{*}, \mathrm{a}^{*}$, and $\mathrm{b}^{*}$ (data not shown, used by Equation 5 to calculate $\Delta \mathrm{E}$ ). There was a loss of luminosity in all samples (reduction of the parameter $\mathrm{L}^{*}$ ), which characterizes the darkening of the meat, and it was noted that the luminosity loss was higher at $10{ }^{\circ} \mathrm{C}$ and was lower with the increase in temperature evaluated. The $\mathrm{a}^{*}$ parameter for all treatments was positive, which indicates the tendency to red meat. However, $\mathrm{a}^{*}$ decreased during the salting period, indicating a reduction in the intensity of the red color during the process. Yalçin and Şeker (2016) [51] also observed a decrease in the parameter $\mathrm{a}^{*}$ after the salting of turkey breast. Sabadini et al. (2001) [45] found a drop in the three-color parameters during the wet salting of meat. The tendency towards yellow color, represented by positive values of $b *$, was higher in samples submitted to lower salting temperatures. In contrast, $\mathrm{b}^{*}$ was lower (in the range of 4 units) and constant during salting only at $30^{\circ} \mathrm{C}$.

The results found to confirm that, in fact, salt exerted a direct influence on the color change of turkey neck meat. The salt influences the color of the meat by two pro-oxidant mechanisms, where the salt increases the oxidation potential of myoglobin and reduces the surface tension of the meat's oxygen, favoring the oxidation of myoglobin to metmyoglobin that has a brownish color $[45,52]$.

The shear force tests were carried out for fresh meat and after $96 \mathrm{~h}$ of dry salting. The small variation in fresh meat used in all treatments is due to the different batches from the turkey neck, with an average shear force of $94.36 \pm 15.28 \mathrm{~N}$. The shear force increased significantly for all samples $(p<0.05)$, regardless the tested temperatures $(p>0.05)$, where at $10{ }^{\circ} \mathrm{C}$ the shear force evolved from $95.28 \pm 19.99 \mathrm{~N}^{\mathrm{aA}}$ to $163.18 \pm 7.67 \mathrm{~N}^{\mathrm{aB}}$; at $15{ }^{\circ} \mathrm{C}\left(87.59 \pm 7.86 \mathrm{~N}^{\mathrm{aA}}\right.$ for $175.00 \pm$ $\left.18.15 \mathrm{~N}^{\mathrm{aB}}\right) ; 20{ }^{\circ} \mathrm{C}\left(100.21 \pm 18.74 \mathrm{~N}^{\mathrm{aA}}\right.$ for $\left.180.30 \pm 17.94 \mathrm{~N}^{\mathrm{aB}}\right)$ and at $30{ }^{\circ} \mathrm{C}\left(84.88 \pm 6.67 \mathrm{~N}^{\mathrm{aA}}\right.$ for $168.63 \pm 13.27 \mathrm{~N}^{\mathrm{aB}}$ ), respectively. In addition to the water loss, the salt gain promotes an increase in the hardness in the meat, where at $15{ }^{\circ} \mathrm{C}$ and $20{ }^{\circ} \mathrm{C}$, the highest hardness of the samples was observed, combined with the more significant salt gains and higher water losses during dry salting (Figure 1b). The results demonstrate that during the salting the meat's hardness increased, as predicted by Ruiz-Ramírez et al. (2005) [53], who associated the increase in hardness to the water loss by the muscle, which in turn is related to the salt content and the $\mathrm{pH}$ of the tissue. In addition to the water loss, the salt also increases the hardness of the tissues because high concentrations of $\mathrm{NaCl}$ promote the compaction of the myofibrillar structure and produce an inhibitory effect on the activity of calpain that works by breaking the $\mathrm{Z}$ lines and increasing the tenderness of the meat [52]. Bampi, Schimidt and Laurindo (2019) [50] during the dry salting of beef cuts found values ranging from $117 \mathrm{~N}$ to $287 \mathrm{~N}$ with different drying methods, which demonstrates that the dehydration method and the form of incorporation of the solutes result in different textures.

\section{CONCLUSION}

The dry salting process of turkey neck cuts can be done at good salt gain rates and water loss rate, with process time of $96 \mathrm{~h}$. These cuts present moisture content approximately $42 \%$ and water activity near 0.76 , similar of the charqui. The salt concentration in the final product had little variation between $8.51 \%$ and $9.47 \%$. The apparent diffusion coefficient for turkey neck meat showed little variation between the temperatures tested and was compatible with other meat products mentioned in the literature. The salt impregnation caused color changes and darkening in the cut meats as shown by the decrease of the $\mathrm{L}^{*}, \mathrm{a}^{*}$, and $\mathrm{b}^{*}$ color parameters. The apparent diffusion coefficient for turkey neck meat showed little variation between the temperatures tested and was compatible with other meat products mentioned in the literature. Therefore, dry salting process has great potential for development new products such as shredded dried meat, meat sausages, among others.

\section{REFERENCES}

1. Barbin DF, Badaró AT, Honorato DCB, Ida EY, Shimokomaki M. Identification of turkey meat and processed products using near infrared spectroscopy. Food Control. 2020;107:1-9, doi: 10.1016/j.foodcont.2019.106816 
2. Baggio SR, Vicente E, Bragagnolo N. Cholesterol oxides, cholesterol, total lipid, and fatty acid composition in turkey meat. J Agric Food Chem. 2002;50:5981-5986, doi: 10.1021/jf020025c

3. Barbut S. The Science of poutry and meat processing. Guelph: [publisher unknown]; 2015. 764 p. Available from: http://www.poultryandmeatprocessing.com/

4. Brasil. Ministério da Agricultura, Pecuária e Abastecimento - MAPA. 2001. Instrução Normativa ${ }^{\circ} 6$, de 15 de Fevereiro de 2001, Regulamento Técnico de Identidade e Qualidade de Produtos Cárneos Salgados.

5. Vidal VAS, Biachi JP, Paglarini CS, Pinton MB, Campagnol PCB, Esmerino EA, da Cruz AG, Morgano M A, Pollonio MAR. Reducing 50\% sodium chloride in healthier jerked beef: An efficient design to ensure suitable stability, technological and sensory properties. Meat Sci. 2019;152:49-57, doi: 10.1016/j.meatsci.2019.02.005

6. Silva FAP, Estévez M, Ferreira VCS, Silva SA, Lemos LTM, Ida EI, Shimokomaki M, Madruga MS. Protein and lipid oxidations in jerky chicken and consequences on sensory quality. LWT - Food Sci Technol. 2018;97:341-348, doi: 10.1016/j.1wt.2018.07.022

7. Bampi M, Domschke NN, Schmidt FC, Laurindo JB. Influence of vacuum application, acid addition and partial replacement of $\mathrm{NaCl}$ by $\mathrm{KCl}$ on the mass transfer during salting of beef cuts. LWT - Food Sci Technol. 2016;74:26-33, doi: 10.1016/j.lwt.2016.07.009

8. Semenoglou I, Dimopoulos G, Tsironi T, Taoukis P. Mathematical modelling of the effect of solution concentration and the combined application of pulsed electric fields on mass transfer during osmotic dehydration of sea bass fillets. Food Bioprod Proc. 2020;121:186-192, doi: 10.1016/j.fbp.2020.02.007

9. Tribuzi G, Schmidt F, Laurindo JB. Operational diagrams for salting-marination processes and quality of cooked mussels. LWT - Food Sci Technol. 2014;59:746-753, doi: 10.1016/j.lwt.2014.06.048

10. Schmidt FC, Carciofi BAM, Laurindo JB. Efeito da impregnação a vácuo na transferência de massa durante o processo de salga de cortes de peito de frango. Ciênc Tecnol Alim. 2008;28(2):366-372, doi: 10.1590/s0101-20612008000200015.

11. Volpato G, Michielin EMZ, Ferreira SRS, Petrus JCC. Kinetics of the diffusion of sodium chloride in chicken breast (pectoralis major) during curing. J Food Eng. 2007;79(3):779-785, doi: 10.1016/j.jfoodeng.2006.02.043.

12. Azuara E, Cortés R, Garcia HS, Beristain CI. Kinetic model for osmotic dehydration and its relationship with Fick's second law. Int J Food Sci Technol. 1992;27:409-418.

13. Assis FR, Morais RMSC, Morais AMMB. Mass transfer in osmotic dehydration of food products: Comparison between mathematical models. Food Eng Rev. 2016;8(2):116-133, doi: 10.1007/s12393015-9123-1

14. Papazoglou-Dimakopoulou D, Katsanidis E. Effect of Maltodextrin, Sodium Chloride, and Liquid Smoke on the Mass Transfer Kinetics and Storage Stability of Osmotically Dehydrated Beef Meat. Food Bioprocess Technol. 2016;10:2034-2045, doi: 10.1007/s11947-017-1973-5

15. Mujaffar S, Sankat C. The mathematical modeling of the osmotic dehydration of shark fillets at different brine temperatures. International J Food Sci Technol. 2005;40:1-12, doi: 10.1111/j.13652621.2005.01086.x

16. Corzo O, Bracho N. Application of Peleg's model to study mass transfer during osmotic dehydration of sardine sheets. J Food Eng. 2006;75:535-541, doi: 10.1016/j.jfoodeng.2005.05.001

17. Chabbouh M, Ahmed SBH, Farhat A, Sahli A, Bellagha S. Studies on the Salting Step of Tunisian Kaddid Meat: Experimental Kinetics, Modeling and Quality. Food Bioprocess Technol. 2012;5:1882-1895, doi: 10.1007/s11947-011-0635-2

18. Schmidt F, Carciofi BAM, Laurindo JB Application of diffusive and empirical models to hydration, dehydration and salt gain during osmotic treatment of chicken breast cuts. J Food Eng. 2009;91:553-559, doi: $10.1016 /$ j.jfoodeng.2008.10.003

19. Telis VRN, Romanelli PF, Gabas AL, Telis-Romero J. Salting kinetics and salt diffusivities in farmed Pantanal caiman muscle. Pesq Agropec Bras. 2003;38(4):529-535, doi: 10.1590/s0100$204 \times 2003000400012$.

20. Sabadini E, Carvalho Jr BC, Sobral PJA, Hubinger MD. Mass transfer and diffusion coefficient determination in the wet and dry salting of meat. Drying Technol: Int J. 1998;16:9-10, 2095-2115, doi: 10.1080/07373939808917514

21. AOAC - Association of Official Analytical Chemists. Official Methods of Analysis of AOAC International. 16th Edition, 4th Revision, Gaithersburg, 1998.

22. Torres EAFS, Campos NC, Duarte M, Garbelotti ML, Philippi ST, Minazzi-Rodrigues RS. Composição centesimal e valor calórico de alimentos de origem animal. Ciênc Tecnol Alim. 2000;20(2):145-150, doi: $10.1590 / \mathrm{S} 0101-20612000000200003$ 
23. Abdullah FAA, Buchtova H. Comparison of qualitative and quantitative properties of the wings, necks and offal of chicken broilers from organic and conventional production systems. Vet Med. 2016;61(11):643-651, doi: 10.17221/286/2015-VETMED

24. Zapata JFF, Moreira RSR, Fuentes MFF, Sampaio EM, Morgano M. Meat mineral content in broilers fed diets without mineral and vitamin supplements. Pesq Agropec Bras. 1998;33(11):1815-1820.

25. Martins MG, Chada PSN, Pena RS. Application of pulsed-vacuum on the salt impregnation process of pirarucu fillet. Food Res Int. 2019;120:407-414, doi: 10.1016/j.foodres.2019.03.016

26. Pignata MC, Viana PT, Covre L, Pignata MC, Lacerda ECQ, Rech JL. Avaliação físico-química e microbiológica na determinação da qualidade da carne de sol. Pubvet: Pub Med Vet Zootec. 2010;4(40):979-1000.

27. Corzo O, Bracho N, Rodríguez J, González M. Predicting the moisture and salt contents of sardine sheets during vacuum pulse osmotic dehydration. J Food Eng. 2007;80:781-790, doi: 10.1016/j.jfoodeng.2006.07.007

28. Martins MG, Pena RS. Combined osmotic dehydration and drying process of pirarucu (Arapaima gigas) fillets. J Food Sci Technol. 2017;54(10):3170-3179, doi: 10.1007/s13197-017-2755-9

29. Maciel RA, Rodrigues AMC, Pena RS. Influence of the process parameters on osmotic dehydration of mapara (Hypophthalmus edentatus) fillet. J Food Sci Technol. 2016;53(1):676-684, doi: 10.1007/s13197015-1999-5

30. Birkeland S, Bjerkeng B. The quality of cold-smoked Atlantic salmon (Salmo salar) as affected by salting method, time and temperature. Int J Food Sci Technol. 2005;40:963-976, doi: 10.1111/j.13652621.2005.01030.x

31. Zhang Q, Xiong S, Liu R, Xu J, Zhao S. Diffusion kinetics of sodium chloride in Grass carp muscle and its diffusion anisotropy. J Food Eng. 2011;107(3-4):311-318, doi: 10.1016/j.jfoodeng.2011.07.011

32. Gómez-Salazar JA, Clemente-Polo G, Sanjuán-Pelliccer N. Review of mathematical models to describe the food salting process. DYNA. 2015;82(190):23-30, doi: 10.15446/dyna.v82n190.42016

33. Turan H, Sonmez G, Çelik MY, Yalçin M, Kaia Y. Effects of different salting process on the storage quality of mediterranean mussel (Mytilus galloprovincialis 1. 1819). J Muscle Foods. 2007;18:380-390, doi: 10.1111/j.1745-4573.2007.00093.x

34. Martínez-López B, Bertelsen NW, Jessen F. Determination of transport properties and mechanistic modeling of the coupled salt and water transport during osmotic dehydration of salmon induced by dry salting. J Food Process Eng. 2019;e13019, doi: 10.1111/jfpe.13019

35. Czerner M, Yeannes MI. Modelling the effect of temperature and lipid content on anchovy (Engraulis anchoita) salting kinetics. J Food Eng. 2013;115:164-172, doi: 10.1016/j.jfoodeng.2012.10.004

36. Corzo O, Bracho N, Rodríguez J. Comparison of Peleg and Azuara et al. models in the modeling mass transfer during pile salting of goat sheets. LWT - Food Sci Technol. 2012;46:448-452, doi: 10.1016/j.lwt.2011.12.002

37. Corzo O, Bracho N, Rodríguez J. Application of Weibull distribution model in describing the pile salting of goat meat slices. Scientific Research and Essays. 2013;8(14):581-58, doi: 10.5897/SRE12.611

38. Chan JTY, Omana DA, Betti M. Effect of ultimate $\mathrm{pH}$ and freezing on the biochemical properties of proteins in turkey breast meat. Food Chem. 2011;127:109-117, doi:10.1016/j.foodchem.2010.12.095 109-117

39. Takahashi SE, Mendes AA, Mori C, Pizzolante CC, Garcia RG, Paz ICA, Pelícia K, Saldanha ESPB, Roça JRO. Meat quality of broilers colonial and industrial type. Rev Cient Elet Med Vet. 2012;9:7-18.

40. Arnau J, Guerrero L, Gou P. Effects of temperature during the last month of ageing and of salting time on dry-cured ham aged for six months. J Sci Food Agric. 1997;74:193-198, doi: 10.1002/(SICI)10970010(199706)74:2<193::AID-JSFA788>3.0.CO;2-O

41. Torres E, Pearson AM, Gray JI, Booren AM, Shimokomaki M. Effect of salt on oxidative changes in preand post-rigor ground beef. Meat Sci. 1988;23(3):151-163, doi: 10.1016/0309-1740(88)90031-9

42. Goli T, Bohuon P, Ricci J, Trystram G, Collignan A. Mass transfer dynamics during the acidic marination of turkey meat. J Food Eng. 2011;104(1):161-168, doi: 10.1016/j.jfoodeng.2010.12.010.

43. Garcia CER, Yamashita F, Youssef EY, Prudencio SH, Shimokomaki M. Effect of carrageenan addition on the yield and functional properties of charqui (Jerked Beef). Braz Arch Biol Technol. 2013;56(2):311318, doi: 10.1590/s1516-89132013000200017.

44. Assis DCS, Santos TM, Ornellas CBD, Drummond FC, Magalhães FC, Santos WLM. Microbiological and physical-chemical characterization and conditions of production and commercialization of sun-dried meat from Salinas, Minas Gerais. Arq Bras Med Vet Zootec. 2019;71(6):1985-1992, doi: 10.1590/16784162-11325

45. Sabadini E, Hubinger MD, Sobral PJA, Carvalho Jr. BC. Change of water activity and meat colour in the elaboration process of dehydrated salted meat. Ciênc Tecnol Alimentos. 2001;21(1):14-19, doi: 10.1590/s0101-20612001000100005. 
46. Salvá BK, Fernández-Diez A, Ramos DD, Caro I, Mateo J. Chemical composition of alpaca (Vicugna pacos) charqui. Food Chem. 2012;130(2):329-334, 2012, doi: 10.1016/j.foodchem.2011.07.046.

47. Brasil. Ministério da Agricultura, Pecuária e Abastecimento - MAPA. 2019. Portaria $n^{\circ} 250$, de 25 de novembro de 2019 - Regulamento Técnico sobre a identidade e requisitos mínimos de qualidade que deve atender o charque, a carne salgada curada e dessecada e o miúdo salgado dessecado.

48. Torres EAFS, Shimokomaki M, Franco BDGM, Landgraf M, Carvalho BC, Santos JC. Parameters determining the quality of charqui, an intermediate moisture meat product. Meat Sci. 1994;38(2):229234, doi: 10.1016/0309-1740(94)90112-0

49. Biscontini TMB, Shimokomaki M, Oliveira SF, Zorn TMT. An ultrastructural observation on charquis, salted and intermediate moisture meat products. Meat Sci. 1996;43(3-4):351-358, doi: 10.1016/s03091740(96)00027-7.

50. Bampi M, Schmidt FC, Laurindo JB. A fast drying method for the production of salted-and-dried meat. Food Sci Technol. 2019;39(2):526-534, doi: 10.1590/fst.24418

51. Yalçin MY, Şeker M. Effect of salt and moisture content reduction on physical and microbiological properties of salted, pressed and freeze dried turkey meat. LWT - Food Sci Technol. 2016;68:153-159, doi: 10.1016/j.lwt.2015.12.032.

52. Nates VA, Ferreira MW, Trindade CS, Pereira C, Santos RM, Silva TAS, Valadares RSS. Tambacu submitted fillets dry salting and salting. Rev Bras Saúde Prod Animal. 2014;15(2):450-458, doi: $10.1590 / \mathrm{s} 1519-99402014000200023$

53. Ruiz-Ramírez J, Arnau J, Serra X, Gou P. Relationship between water content, $\mathrm{NaCl}$ content, $\mathrm{pH}$ and texture parameters in dry-cured muscles. Meat Sci. 2005;70(4):579-587, doi: 10.1016/j.meatsci.2005.02.007. 